\title{
MANAJEMEN PENGEMBANGAN PROFESIONALISME GURU SLTA DI KABUPATEN HULU SUNGAI UTARA
}

\author{
Mahdalina \\ Sekolah Tinggi Ilmu Administrasi STIA Amuntai \\ Jl. Bihman Villa Amuntai HSU Kal-Sel \\ Phone 052762168 Faks. 052762520
}

\begin{abstract}
Abstrak
Penelitian ini bertujuan mengetahui tentang model-model pengembangan profesionalisme guru dalam meningkatkan tugas dan beban kerja sebagai seorang guru yang professional. Metode yang digunakan dalam penelitian yaitu deskriptif analisis. Hasil penelitian ini adalah terdapat 10 model manajemen pengembangan profesionalisme guru antara lain: (1) Program peningkatan kualifikasi guru, (2) Program penyetaraan dan sertifikasi, (3)Program pendidikan supervise pendidikan, (4) Program pemberdayaan MGMP (Musyawarah Guru Mata Pelajaran), (5) Simposium guru, (6) Program pelatihan guru tradisional, (7) Berpartisipasi dalam pertemuan ilmiah, (8) Melakukan penelitian (khususnya penelitian tindakan kelas), (9) Berpartisipasi dan aktif dalam organisasi profesi, (10) Menggalang kerjasama dengan teman sejawat.
\end{abstract}

Kata-Kata Kunci: manajemen, pengembangan, profesionalisme guru

\section{MANAGEMENT OF THE DEVELOPMENT OF TEACHER PROFESSIONALISM OF SLTA IN KABUPATEN HULU SUNGAI UTARA}

\begin{abstract}
Management Development of Professionalism of High School Teachers in Hulu Sungai Utara District. This study aims to find out the models of professional development of teachers in improving the task and workload as a professional teacher. The method used in this research is descriptive analysis. The results of this study are 10 models of teacher professional development management, among others: (1) Teacher qualification improvement program, (2) Equivalency and certification program, (3) Educational supervision education program, (4) MGMP empowerment program (Subject Teacher Consultative), (5) Simposium teachers, (6) Traditional teacher training programs, (7) Participate in scientific meetings, (8) Conduct research (especially classroom action research), (9) Participate and be active in professional organizations, (10) Raise cooperation with peers.
\end{abstract}

Key Words: management, development, professionalism of teacher

\section{Pendahuluan}

Sudarwan Danim (2002:51) menjelaskan bahwa pengembangan profesionalisme guru diartikan untuk memenuhi tiga kebutuhan. Pertama, Kebutuhan social untuk meningkatkan kemampuan system pendidikan yang efesien dan manusiawi dan melaksanakan adaptasi untuk penyusunan social. Kedua, Kebutuhan untuk menemukan cara-cara dalam membantu staf pendidikan sebagai rangka mengembangkan pribadinya secara luas. Ketiga, Kebutuhan untuk mengembangkan dan mendorong kehidupan pribadinya, seperti halnya membantu siswa dalam mengembangkan keinginan dan keyakinan untuk memenuhi keinginan pribadi yang sesuai dengan potensi dasarnaya. 
Guru atau tenaga pendidik merupakan seorang yang bertugas menyampaikan pengetahuan kepada siswanya. Seorang guru professional merupakan seorang guru yang memenuhi kualifikasi pendidikan serta kompetensi yang harus tertentu. Untuk mencapai pendidikan yang bermutu, maka guru atau tenaga pendidik sebagai salah satu tonggak keberhasilan pendidikan yang bermutu.Pengembangan mutu guru meliputi tig hal yaitu: pengembangan mutu profesi, kompetensi, serta kinerja guru dilakukan sesuai dengan Undang-undang Nomor 14 tahun 2005 tetang guru dan dosen.

Seperti yang diungkapkan Djohar (2006), penelitian dan pengmbangan mutu kompetensi guru berkaitan dengan kemampuan guru dalam menggunakan bidang studi atau mata pelajaran sebagai alat pendidikan. Penelitian dan pengembangan kinerja guru yang terkait dengan kompetensi menjadi tanggung jawab Universitas-LPTK. Kinerja awal guru sangat ditentukan dari hasil pendidikan guru yang selanjutnya akan berkembang sesuai pengalaman mereka.

Surplan ( 2006) juga menjelaskan bahwa pengembangan profesi khusus diwajibkan bagi kenaikan pangkat/jabatan mulai dari guru Pembina atau pengawas sekolah utama. Oleh karena itu, penting bagi para guru pendidikan untuk memahami pengembangan yang berkaitan dengan mutu guru.

Tujuan penelitian ini adalah mengetahui tentang pengembangan dan peningkatan tugas dan beban kerja sebagai seorang guru. Manfaat penelitian ini terdiri atas; manfaat teorities dan praktis. Bagi penulis dan pembaca untuk mengetahui maksud dari Pengembangan Manajemen Profesionalisme guru, serta mengetahui model-model pengembangan profesi guru semantara dari manfaat bagi penulis dan pembaca.

Profesionalisme dapat diartikan sebagai komitmen para anggota suatu profesi untuk meningkatkan kemampuan profesioanalnya, dan terus menerus mengembangkan strategi-strategi yang digunaknnya dalam melakukan pekerjaan sebagai profesi. Direktorat Jenderal Pendidikan Dasar dan Menengah Dapertemen Pendidikan Nasional (2005) menyebutkan beberapa alternatif program pengembangan profesionalisme guru, sebagai berikut: (1) Program peningkatan kualifikasi pendidikan guru, (2) Program penyetaraan dan sertifikasi, (3) Program supervise pendidikan, (4) Program pemberdayaan MGMP (Musyawarah Guru Mata Pelajaran), (5) Simpusium guru, (6) Program pelatihan tradisional, (7) Membaca dan menulis jurnal, (8) Berpartisipasi dalam pertemuan ilmiah, (9) Melakukan penelitian (PTK), (10) Berpartisipasi dan aktif dalam organisasi pofesi, (11) Menggalang kerjasama dengan rekan sejawat. Profesi keguruan mempunyai tugas utama melayani masyarakat dalam dunia pendidikan, sejalan dengan itu jelas kiranya bahwa profesionalisme dalam bidang keguruan mengandung arti peningkatan dalam rangka pencapaian secara optimal layanan yang akan diberikan kepada masyarakat. Untuk meningkatkan mutu pendidikan di jenjang sekolah SLTA yang menjadi objek penelitian ini, maka profesionlisme menjadi keharusan terlebih lagi 
apabila dilihat dalam kondisi SDM yang ada disekolah tersebut yang masih kurang dalam hal pelaksanaan pendidikan seperti: (1) Perkmbangan Iptek, (2) Persaingan global bagi lulusan pendidikan, (3) Otonomi daerah, dan (4) Implementasi Kurikulum Tingkat Satuan Pendidikan (KTSP).

\section{Metode}

Penelitian ini merupakan penelitian dengan pendekatan kualitatif. Penelitian kualitatif lebih banyak ditujukan pada pembentukan teori subtansi berdasarkan pada konsep-konsep yang timbul dari data imperes (Margono,2009:35). Penelitian ini dilakukan untuk mengetahui tentang pengembangan profesionalisme guru serta model-model pengembangan profesi guru. Jenis penelitian yang digunakan adalah analisis data kasus. Penelitian ini menggunakan mtode deskreftif analisis. Imforman dalam wawancara para guru SLTA yang ada di Kabupaten Hulu Sungai Utara, yang merupakan sumber data pengembangan profesionalsme yang didapat dari hasil wawancara dari beberapa orang guru SLTA yang ada di Kabupaten Hulu Sungai Utara yang merupakan data yang diperoleh dalam penelitian ini. Teknik wawancara merupakan teknik yang digunakan penulis dalam penelitian ini, titik kunci dalam wawancara adalah bahwa ia sangat fleksibel dan mengizinkan dalam memahami perspektif orang-orang yang diwawancarai (Daymon dan Holloway, 2008:2019).

\section{Hasil dan Pembahasan}

\section{Program Peningkatan Kualifikasi Pendidikan Guru}

Sesuai dengan peraturan yang berlaku bahwa kualifikasi pendidikn guru adalah minimal S1 dari program keguruan. Ternyata faktanya di Kabupaten Hulu Sungai Utara masih ada guruguru yang belum memenuhi atau memiliki kualifikasi pendidikan minimal S1, maka dari itu guru-guru tersebut harus mengikuti pendidikan S1 keguruan. Program ini berupa program kelanjutan studi dalam bentuk tugas belajar.

Dengan adanya program sertifikasi pendidik diharapkan kompetensi guru sebagai pengajar akan menigkat sesuai dengan standar yang telah ditetapkan dengan kompetensi guru yang memenuhi standar minimal dari kesejahteraan yang demikian diharapkan kinerja guru dalam meningkatkan hasil belajar siswa.

\section{Program Penyetaraan Sertifikasi}

Program ini diperuntukkan bagi guru mengajar tidak sesuai denga latar belakang pendidikannya atau bukan berasal dari program pendidikan keguruaan. Hal tersebut terjadi karena sekolah SLTA di Kabupaten Hulu Sungai Utara mengalami keterbatasan atau kelebihan 
guru mata pelajaran tertentu, sehingga akibatnya sering terjadi kualifikasi pendidikan mereka lebih tinggi dari kualifikasi yang dituntut namun faktanya tidak sesuai, misalnya berizajah S1 tetapi bukan pendidikannya. Mereka dapat diikutsertakan dalam program penyetaraan atau sertifikasi guru yang berkompoten.

Program penyetaraan sertifikasi ini tujuannya untuk meningkatkan kualitas sekolah. Salah satunya dengan penyetaraan pangkat guru non PNS dan PNS, sebagai perwujutan dan peningkatan mutu guru. Dengan demikian sertifikasi guru diharapkan dapat meningkatkan kesempatan dan kesejahteraan guru agar lebih baik lagi.

\section{Program Supervisi Pendidikan}

Dalam praktik pembelajaran di kelas masih sering ditemui guru-guru yang ditingkatkan profesioanlismenya dalam proses belajar mengajarnya. Sering ada persepsi yang salah atau kurang tepat dimana tugas seorang supervisor sering dimaknai sebagai tugas untuk mencari kesalahan atau untuk mengadili para guru, padahal tujuannya adalah untuk meningkatkn efektifitas dan efisiensi proses belajar mengajar lebih efektif dan efisien lagi.

Di samping asfek kemampuan professional guru yang berdampak pada pengelolaan proses belajar mengajar sehari-hari. Isi program Pembina harus memperhatikan pula persoalanpersoalan yang dihadapi guru dalam melaksanakan gagasan baru yang diperoleh melalui penataraan atau kebijakan baru, sebaiknya para pengawas hendaknya peka terhadap kebutuhan guru untuk memenuhi angka kredit bagi kenaikan jabatan fungsional.

\section{Program Pemberdayaan MGMP (Musyawarah Guru Mata Pelajaran)}

MGMP adalah suatu forum atau wadah kerja dimana masing-masing sekolah yang terdiri daru dua unsur yaitu: Mata pelajaran adalah guru SMP dan SLTA Negeri atau Swasta yang mengasuh dan bertanggung jawab dalam mengelola mata pelajaran yang ditetapkan dalam kurikulum.

Guru bertugas mengimplementasikan kurikulum dikelas dalam hal ini semua guru setingkat SLTA di Kabupaten Hulu Sungai Utara dituntut dalam kerjasama yang optimal di antara para guru. Dengan MGMP ini diharapkan akan meningkatkan profesionaisme guru dalam melaksanakan pembelajaran yang bermutu sesuai kebutuhan peserta didik. Wadah profesi sangat diperlukan dalam memberikan kualifikasi peningkatan keprofesionalisme para anggotanya. 


\section{Simposium Guru}

Selain MGMP ada forum lain yang dapat digunakan sebagai wadah untuk saling berbagi pengetahuan dan pemecaahan masalah yang terjadi dalam proses pembelajaran yaitu symposium, melalui forum symposium guru di tingkat sekolah SLTA di Hulu Sungai Utara ini dapat diharapkan para guru menyebarluaskan upaya-upaya kreatif dalam pemecahan masalah. Forum ini selain sebagai media untuk sharing pengalaman berfungsi untuk kompetensi antar guru denagn mnampilkan guru-guru yang berprestasi dalam berbagai bidang, misalnya dalam penggunaan metode pembelajaran, hasil tindakan kelas atau penulisan karya ilmiah.

\section{Program Pelatihan Tradisional}

Pelatihan ini bertujuan untuk mengacu pada suatu aspek khusus khusus yang sifatnya actual dan penting untuk diketahui oleh para guru SLTA di Kabupaten Hulu Sungai Utara , misalnya: CTL, KTSP, PTK, Penulisan Karya Ilmiah, dan lain sebagainya.

\section{Partisipasi dalam Pertemuan Ilmiah}

Partisipasi guru minimal dilakukan pada kegiatan komperensi atau pertemuan ilmiah setiap tahun akan memberikan kontribusi yang berharga dan sekaligus membangun profesionalisme penyampaian makalah utama, kegiatan diskusi,kelompok kecil, pameran ilmiah, pertemuan ilmiah untuk bertukar pikiran atau ide-ide baru, dan sebagainya, serta berintegrasi untuk memberikan kesempatan pada guru dalam memberikan kesempatan kepada para guru di Kabupaten Hulu Sungai Utara untuk tumbuh sebagai seorang professional.

\section{Melakukan Penelitian ( Khusus Penelitian Tindakan Kelas)}

Penelitian tindakan kelas (PTK) yang merupakan studi sistematik yang dilakukan guru melalui kerjasama atau tidak dengan ahli pendidik dan sekaligus meningkatkan praktik pembelajaran secara terus menerus juga merupakan strategi yang tepat untuk meningkatkan profesionalisme para guru di Kabupaten Hulu Sungai Utara berbagai kajian yang bersifat reflektif oleh guru yang dibutuhkan untuk meningkatkan kemantapan rasional serta memperdalam pemahaman terhadap tindakan yang dilakukan dalam melaksanakan tugasnya, dan memperbaiki kondisi di mana praktik pembelajaran berlangsung akan bermanfaat sebagai inovasi pendidikan.

\section{Berpartisipasi dan Aktif dalam Organisasi Potensi}

Ikut serta menjadi anggota organisasi atau komunitas professional juga akan meningkatkan profesionalisme guru SLTA di Kabupaten Hulu Sungai Utara. Organisasi atau komunitas 
professional biasanya akan melayani anggotanya untuk selalu mengembangkan hubungan yang erat dengan masyarakat. Dalam hal ini yang terpenting adalah guru harus pandai memilih satu bentuk organisasi professional yang dapat memberikan manfaat untuk bagi dirinya melalui bentuk investasi waktu dan tenaga.

\section{Menggalang Kerjasama dengan Teman Sejawat}

Kerjasama dengan teman sejawat seprofesi sangat menguntungkan bagi pengembangan profesionalisme guru di sekolah SLTA Kabupaten Hulu Sungai Utara. Banyak hal yang didapat dan dipecahkan dan dilakukan berkat kerjasama, seperti: Penelitian Tindakan Kelas, berpartisipasi dari kegiatan ilmiah, dan lain sebagainya.

Cara ini dapat dilakukan untuk semu ajenis tenaga kependidikan (baik tenaga structural, fungsional, maupun teknis), berorentasi pada perubahan tingkah laku dalam rangka peningkatan kemampuan professional, dirintis untuk mengarahkab dan melatih seseorang sebeum menduduki jabatan, pengembangan yang menyangkut jenjang karir sebaiknya disesuaikan dengan ktegoro masing-masing jenis tenaga kependidikan itu sendiri.

\section{Kesimpulan dan Saran}

\section{Simpulan}

Pengembangan profesionalisme guru dimaksudkan untuk memenuhi tiga kebutuhan, salah satunya adalah kebutuhan sosial untuk meningkatkan kemampuan sistem pendidikan yang efisien dan manusiawi serta melakukan adaptasi untuk penyusunan kebutuhan-kebutuhan sosial. Modelmodel pengembangan profesionalisme guru, diantaranya adalah sebagai berikut: Program peningkatan kualifikasi pendidikan guru, Program Penyetaraan dan sertifikasi, Program supervise pendidikan, Program pemberdayaan MGMP (Musyawarah Guru Mata Pelajaran), Simposium guru, Program pelatihan tradisional, Membaca dan menulis jurnal karya ilmiah, Melakukan penelitian tindakan kelas serta berpartisipasi dan aktif dalam organisasi potensi.

\section{Saran}

Peningkatan manajemen profesionalisme guru SLTA di Kabupaten Hulu Sungai Utara merupakan upaya peningkatan segala sumber daya dan usaha dalam rangka pencapaian secara optimal layanan yang akan diberikan kepada masyarakat. Maka profesioanlisme guru (pendidik) merupakan suatu keharusan terlebih lagi apabila kita melihat kondisi objektif saat ini berkaitan dengan berbagai hal yang ditemui dalam melaksanakan pendidikan, yaitu: (1) Perkembangan Iptek, (2) Persaingan Global, (3) Otonomi Daerah, (4) Implementasi KurikulumnTingkat Satuan Pendidikan (KTSP). 
Vol.2 No.2, 1 Oktober 2017

\section{Daftar Rujukan}

Djohar. 2006. Guru Pendidikan dan Pembinaan (Penerapan dalam Pendidikan dan UU Guru): Yogyakarta:CV Grafika Indah.

Trianto. 2011. Penagntar Penelitian Pendidikan bagi Pengembangan Profesi Pendidikan dan Tenaga Kependidikan. Jakarta: Kencana Prenada Media Group.

Surplan. 2006. Guru sebagai Profesi. Yogyakarta: Hikayat.

Masnur Muslich 2007 Sertifikasi Guru Menuju Profesionalisme Pendidik. Jakarta 